\title{
A.JO'ГE
}

African Journal of Teacher Education

ISSN 1916-7822. A Journal of Spread Corporation

Volume $82019 \quad$ Pages 25-52

\section{Preparing Namibian Student Teachers to Teach Literacy in Mother Tongue}

\author{
Alina Amukushu-Niipare \\ University of Pretoria
}

\begin{abstract}
Scholars of language teaching agree that the development of initial literacy is best achieved when taught in the mother tongue. Namibia's language policy for schools prescribes teaching using mother tongue or the predominant local language as a medium of instruction during the first three years of schooling. This study reports on a study of how Namibian lecturers prepare student teachers to teach literacy in mother tongue (Oshikwanyama and Oshindonga) dialects of Oshiwambo language. Data were collected through classroom observations, semi-structured interviews and document analysis. Content analysis was used to analyse the data. The main findings are that most of the lecturers were proficient in the languages in question and they fluently explained the literacy content in Oshikwanyama and Oshindonga. However, the preparation was constrained by a lack of prescribed books in the African languages. The study aims at filling a gap in the literature on how Namibian student teachers are prepared to teach literacy in mother tongue grounded within a sociocultural perspective.
\end{abstract}

Keywords: mother tongue, first language, literacy teaching, teacher preparation, student teacher, Oshikwanyama, Oshindonga, Oshiwambo, Namibia.

\section{Introduction}

There has been a strong advocacy for the use of the mother tongue language in the early grades, based on the argument that children who receive schooling in their mother tongue in these grades acquire better literacy levels. Using the mother tongue or the first language of the learners enable learners to use the knowledge and skills acquired as a bridge to the acquisition of a new language (Ball, 2010; 
Petal, 2012).The overall argument for mother tongue education in early learning as mentioned by prominent scholars is based on cognitive, emotional, psychological, sociological and cultural aspects as well as pedagogical advantages (Ouane \& Glanz, 2005; Rodseth, 2002). While research acknowledges the value of mother tongue-based education in children's learning, it has been observed that the success of mother tongue education depends on the recruitment of teachers who can not only speak the language of the community but who also can read, write, and use that language in an academic context (Dutcher, 2003; Lewin, 2004). This needs training because even if teachers speak the local language, it does not mean that they can read, write and teach using the same (Dutcher, 2003). Gacheche, (2010) findings indicate that teachers who speak a child's mother tongue (L1) can also teach in it. It is however idealistic to expect that teachers who are involved in the development and teaching of mother tongue programme would possess diverse language proficiency and teaching experiences (Purdie, et al., 2008). There is therefore a need for teachers to be adequately prepared to teach literacy in mother tongue as a medium of instruction in schools.

The literature on mother tongue teacher preparation argues that teachers who are well prepared to teach literacy in mother tongue make a positive impact on their learners' learning outcomes (Karan \& Morren, 2013; Amissah, 2001; Benson \& Plüddemann, 2010). They need to show adequate knowledge, skills and competencies of the language used as a medium of instruction in schools (Karan \& Morren, 2013). However, there is limited research on how pre-service teachers in Namibia and elsewhere are prepared to teach literacy in mother tongue. Extant studies conducted on mother tongue teachers' preparation are largely on developed countries and have focused mainly on only reading and writing (Perry, 212; King, 2003).

This paper forms part of the PhD study undertaken at the University of Namibia (UNAM). It examined the extent to which the initial teacher education programme in Namibia prepares student teachers to teach literacy in the mother tongue language in the junior primary grades (Grades 1-3) of the Namibian schooling system. The main study strove to answer the following question: how are student teachers prepared to teach literacy in the mother tongue (Oshindonga and Oshikwanyama). Therefore, the purpose of this paper is mainly to give detail explanations of how teachers were prepared to teach literacy in mother tongue (Oshindonga and Oshikwanyama). 


\section{Teacher Training in Namibia}

The responsibility for teacher education in Namibia was shared between the Colleges of Education and the University of Namibia. The three types of education programmes were developed after independence including, namely, the Basic Education Teacher Diploma (BETD), which was a threeyear course aimed at preparing teachers for basic education (Grades 1-10); the senior secondary school teacher qualification which was offered by the University of Namibia; and finally the technical and vocational education Instructor qualification which prepared teachers for instruction in pre-vocational skills in vocational and other technical institutions (Angula, 1993). The BETD was offered in the four colleges of Education (Rundu College, Caprivi College, Ongwediva College and Windhoek College).

In 2010, the four College of education merged with the University of Namibia and became UNAM campuses. The University has since begun to offer teacher education programmes for junior primary school teachers. The merger of the Colleges of Education and the University of Namibia meant that the university has had to adapt different methodologies in order to prepare teachers for all the school phases adequately. Accordingly, in 2011, the university introduced a four-year Bachelor of Education (pre-primary and lower primary) for junior primary teachers and aimed at preparing teachers to be competent to teach in English and a Namibian language and also to be able successfully to effect the transition from a Namibian language as the medium of instruction to English (Language Policy for Schools (1992).

\section{Theoretical framework}

The main study drew on two dominant views underlying literacy learning: sociocultural and cognitive perspectives.

\section{The sociocultural perspective}

A sociocultural is based on Vygotsky's ideas, which propose that all human activities taking place within a cultural context are mediated by language and other symbols, and can be understood in the context of their historical development perspective (Davidson, 2010).

The above perspective requires finding out how children interpret their relations with others and how they learn the process of interpreting and encoding the world around them (Perez, 2004 in Hossain, 
2013). Learning is mediated 'through language, in this context learners' first language, facilitated by drawing on the contexts familiar to the learners so that meaning making is prioritized' (Westbrook et al., 2013, p.10).

Learning to teach is a sociocultural and a mediated process that involves interactions between individuals such as peers, learners, teachers and mentors (Hammond \& Bransford, 2005). The interaction requires supervision and coaching to enable student teachers apply different kinds of knowledge in the classroom (Hammond \& Bransford, 2005). The process is influenced by beliefs, attitudes, and prior experiences about teaching that may cause tension between student teachers' beliefs and what they learn in their initial teacher education courses (Nomlomo \& Desai, 2014). Therefore, it is useful that teacher educations takes cognisance of this development and ensure that teachers are trained in such a way that they acknowledge their learners' cultural experiences.

A sociocultural theory of literacy development and practice is relevant to this study as it aims to ascertain how well student teachers are prepared to teach literacy in mother tongue in Namibia and gauge their familiarity with the interactions and engagements that must occur for literacy teaching and learning. This study attempts to apply the sociocultural theory to mother tongue literacy teaching in Namibia. It seeks to establish the relevance of the sociocultural theories to developing countries like Namibia.

\section{The cognitive perspective}

The cognitive approach is referred to as bottom-up approach because it focuses on understanding the text by combining the smallest units of the whole (Gains, 2010). In other words, the process starts with letter knowledge; moving on to consonants and blending them into syllables to form words and finally sentences (Davidson, 2010). It is assumed that children learn and progress in a similar way, and the skills are to be taught in isolation and in sequence. The role of the teacher in the cognitive approach is to ensure that each learner develops phonic and decoding skills and constructs meaning from the text read. This study thus drew on the two perspectives. The cognitive approach guides instructional activities in the classroom and could explain the difficulties that learners may experience with acquiring literacy, whereas a socio-cultural approach offers some explanations regarding the broader literacy learning context. The two perspectives, therefore, complement each other (Davidson, 2010). 


\section{The context}

The study was conducted at the University of Namibia's campuses that train Lower primary school teachers to teach in mother tongue instruction in schools. Out of the university's four campuses, two were purposefully selected for this study; one in the central part of the country that offered languages such as Khoekhoegowab, Afrikaans, Otjiherero Oshindonga Oahikwanyama and English and the second in the northern part of the country offered Oshindonga, Oshikwanyama and English. These campuses were chosen since they train student teachers in the Oshindonga and Oshikwanyama, the dialects of Oshiwambo language that are used as mediums of instruction in the relevant schools. The campuses where the interviews and observations were conducted are indicated as pseudonyms Campus A and Campus B.

\section{The research method}

The study used a qualitative case study methodology to enable the researcher gain an in-depth understanding of the views and experiences of the lecturers on how they prepared pre-primary and lower primary BEd student teachers to teach literacy through mother tongue-based instruction. The methods of data collection utilized included semi-structured interviews and classroom observations. The face-to-face, semi-structured interviews were conducted with the four lecturers of Oshindonga and Oshikwanyama on the two campuses mentioned above. The aim of the interview was to ascertain the lecturer's views on how they were preparing future teachers to teach mother tongue literacy; on their perceptions and understanding of mother tongue teaching; and whether their teaching support the policy of mother tongue teaching in schools. Lecturers were also asked how the student teachers' sociocultural characteristics were acknowledged and how student teachers were assisted to link what they knew already with what they were learning (see the questions Appendix 1).

Classroom observations were also carried out on the four lecturers teaching Oshindonga and Oshikwanyama to second and third year student teachers. It was planned that the lecturers would be observed teaching the fourth year students. However, the modular approach used by the university prevented this as the listening and speaking module was offered only in the second year of training while the reading and writing module came up in the third year. Accordingly, the researcher was forced to observe lecturers presenting mother tongue literacy content to the second and third-year students rather than the fourth-year students previously arranged for. 
The classroom observations at the two campuses focused on observing lecturers training student teachers on how to teacher literacy in mother tongue (Oshindonga and Oshikwanyama), how they assess the approaches employed to measure the mastery of the literacy content in terms of how mother tongue literacy was learned and managed, and in terms of conceiving classroom interactions as a social practice. The observations also focused on the way in which the student teachers' own personal and socio-cultural experiences were used. Overall, 28 classroom observations were carried out in the four classes during the Oshindonga and Oshikwanyama periods, focusing on literacy teaching (listening, speaking, reading and writing). Nadia, Grace and Saara (pseudonyms) offered eight (8) lessons each, and Maria six (6).

The data from the observations and the interviews was compared to establish relationship between what participants had said in the interviews and what they did in practice in order to determine whether people did what they said or not and behaved in the ways they claimed to behave (Benson, 2010; Cohen et al., 2013).

\section{Participants}

There were four (female) lecturers taught Oshindonga and Oshikwanyama in the two Campuses. All four lecturers agreed to participate and were all interviewed as well as observed teaching. Campus A had one lecturer only who was responsible for teaching the above dialects of the Oshiwambo language. This lecturer taught all the levels, namely, first, second, third and fourth year students in both Oshindonga and Oshikwanyama, while campus B has three teacher educators, one responsible for Oshikwanyama and the other two for the Oshindonga dialects of the Oshiwambo language.

At the time of the study, 75 fourth year student teachers were enrolled for Oshindonga and Oshikwanyama from the two selected campuses. Out of the mentioned number, 30 student teachers were selected to be interviewed and were agreed to participate in the study. Ten (10) of these 30 student teachers were observed teaching mother tongue literacy in schools during the School Based Studies/Teaching Practice. It was stipulated in the University admission requirements (Prospectus (2016) that student teachers who wished to specialise in pre-primary and lower primary educations were required to pass both English and an African Language and, therefore, they should study English Language Education and a Namibian language. 


\section{Data Analysis}

Firstly, all the transcripts were carefully transcribed and the field notes expanded upon immediately after each observation. Once the expanded notes for each lesson observed had been transcribed, files for both the interviews and the classroom observation were created on the computer in which these notes were stored. I studied the data acquired several times in order to obtain a sense of both the field notes and interview transcripts. I had written notes in the margins of the field notes and transcripts and these helped greatly in the process of exploring the database (Creswell, 2013) and attaching meaning to the pieces of data (Lofland, Snow, Anderson \& Lofland, 2006). Those labels enabled me to summarise data, identify patterns and pull together themes.

\section{Ethical consideration}

Written permission was obtained from the Faculty of Education at the University of Pretoria. The study-involved interaction with lecturers and student teachers during which their personal views about literacy were solicited and the information they supplied used as data. Accordingly, appropriate and required ethical protocol underpinned the carrying out of the study. The identities of the campuses as well as the lecturers are protected using pseudonyms. Therefore, the particular campuses are masked and the lecturers' names used in this paper are not their real names.

\section{Findings and Discussions}

\section{Lecturer's background information}

It must be remembered that this study was seeking to answer the question as to how the lecturers were preparing future student teachers to teach literacy using the mother tongue of the learners as the medium of instruction in schools. In order to acquire a clear understanding of how student teacher were being prepared to teach literacy in Oshindonga and Oshikwanyama, I was interested to learn more about the lecturers' profile and also their teaching preparation experiences in order to ascertain whether these had an impact on mother tongue literacy teaching preparation.

Studies of primary teacher education have indicated that lecturers do not generally have much professional experience of primary classroom teaching (Mulkeen, 2010; Akyeampong, et al, 2011). This is generally true of some of the lecturers in this study who were neither trained to teach at lower 
grades nor to teach mother tongue literacy. The findings of this study indicate that the majority of the lecturers had not been trained either to teach the lower grades or to teach mother tongue literacy, but they were rather trained as specialist language teachers. The training and teaching experiences of the lecturers who participated in this study are discussed below:

Nadia had studied for a senior secondary diploma first and subsequently for a
degree. Her first years of teaching were at the junior secondary level, the next
four years at the senior secondary level after which she was appointed to teach at
the teachers' training college, which provided training for primary school student
teachers.
Grace had qualified to teach Grades 5 to 7 (senior primary) and Grades 8 to 10
(junior secondary). During her training, Oshikwanyama was taught in English.
Maria had qualified to teach at primary school level, secondary school level as
well as at teacher training institutions. During her primary school teacher training,
Maria studied Oshindonga as a subject as well as the method of language
teaching. However, both her secondary education and her higher education
diploma did not include a record of Oshindonga although they included English
as a language.
Although Sara was fortunate to have been trained to teach in mother tongue, this
training had not included practical teaching. It was focused more on the theory
and the structure of mother tongue as a language. Sara commented:
It was thus clear from the lecturers' experiences discussed above that the majority
of the but in the 1990 s... we were taught in Oshindonga but it wasn't much on how
they taught us the content or the structure of the language.


senior primary and senior secondary. In other words, their training and experience in respect of teaching young children appeared to be minimal.

In view of the fact that the majority of the lecturers observed had not been trained to teach the junior primary phase, I was interested to ascertain the extent of the lecturers' experience in preparing student teachers for mother tongue literacy in the early grades. The discussion with the lecturers revealed that at first, they had been anxious because they had not known much about the training of teachers for this phase. For example, Nadia stated that at first she was clueless but only later realised the importance of junior primary training and that one had to make a difference. She further explained that her involvement in the preparation of pre and lower primary future teachers had been a revelation for her because she had so enjoyed creating and telling stories and singing and rhyming with the students. However, in order for lecturers to start with the preparation of the mother tongue literacy teachers, they had to go through different capacity building experiences and attend workshops and trainings sessions. In addition, officials in the pre-and lower primary departments who had experience in literacy teaching supported them. For example, the head of department (HOD) had greatly supported them and given them a crash course in a one-day workshop on what lower primary is all about, the philosophy of teaching young children, and teaching through songs and handwriting. Nadia also mentioned that they used to have co-teaching where those who were more experienced taught others who observed them.

\section{Lecturers perceptions of the mother tongue literacy-teaching policy}

The critical question during the interviews requires lecturers' to tell their personal philosophies of mother tongue teaching. It was clearly observed that the lecturers regarded mother tongue teaching as important in children's learning. They maintained that when the language used at home is the same as the language used at school the mother tongue links both home and the school together. They further argued that, by mastering their first language, learners would be able to use the skills acquired to learn a second language. For example, Nadia, a lecturer from campus A, explained:

When learning in the mother tongue, especially in the first year, it connects and builds up the foundation for the second language ... it links with the research finding that those children whose oral language is good in their mother tongue also benefit in relation to the acquisition of reading as well as numeracy skills. 
However, the lecturers voiced their concerns about the lack of understanding on the part of the student teachers, community members, and parents who regarded mother tongue teaching unfavourably as having no economic value.

\section{Mother tongue literacy practice}

In order to obtain data on the way in which the student teachers were trained to teach literacy in the mother tongue, classroom observations of four lecturers teaching literacy in Oshindonga and Oshikwanyama were carried out. The purpose of these observations was to obtain an understanding of the methods, approaches and strategies which the lecturers in Oshindonga and Oshikwanyama used to prepare student teachers to teach literacy when these two languages were used as the medium of instruction in schools. The classroom observations criteria included:

1. teaching methods

2. literacy methods and strategies used to prepare students to teach mother tongue literacy, i.e. the way in which literacy is taught and managed

3. the approaches to assessment used

4. the availability of mother tongue teaching resources

5. classroom interaction by way of a social practice

6. type of literacy skills being taught

7. connection between previous experiences and new information

8. the language proficiency of the lecturers.

\section{Presentation/teaching methods}

The mother tongue literacy content in most cases was implemented using a face-to-face method and was delivered in Oshikwanyama and Oshindonga to a large number of students. All the lecturers I observed used PowerPoint presentations to communicate literacy content to student teachers in Oshindonga and Oshikwanyama. Most of the lecturers' teaching was observed taking place in the lecturer rooms. Some lecture rooms were not suitable for training student teachers who will teach preand lower primary grades because they do not share any characteristics of a lower primary classroom. 
Below are some descriptions of the teaching methods which the lecturers used to teach mother tongue literacy.

\section{Lecture method}

In the Oshindonga and Oshikwanyama classrooms I observed, the method used and that dominated the content delivery was lecture method. For example, Nadia presented a literacy content lesson that was on how to teach literacy using stories, poems, songs, rhymes and games. She read out the notes on prelistening, pre-reading and pre-writing. She stood in front of the class explaining the notes that were on the screen. As a result of lecturing, the student teachers' engagement during the lesson was limited. Each lecturer found it difficult to get the attention of all the student teachers. The interaction and communication between the lecturers and the student teachers was minimal because only the students that sat in front of the class followed and participated in the discussion. Students that sat at the back of the class were just making noise and busy operating their cell phones, while some were busy on their laptops. In most of the lessons I observed, lecturers did little to engage or actively involve all student teachers in the teaching and learning activities, and thus, student teachers looked passive and disconnected, which may have hindered effective mother tongue literacy learning. Although the lecturers all allowed the student teachers to answer questions or explain things to show understanding, little was done to put them in pairs or groups to discuss or to share their views and opinions with the rest of the class in a plenary session.

During the lesson presentations according to the observation criteria, there was no evidence that student teachers were being evaluated or assessed; instead, the lecturers asked questions that few student teachers could answer. It was observed that some lecturers failed to encourage the student teachers to expand their responses by asking for additional thoughts from others (Means \& Nails, 2004). It was however, noted that these lecturers still did not have sufficient skills on lecturing methods. It could be argued here that when one talks of teaching methods it does not necessarily mean telling or giving the information, but rather including strategies that can help student teachers connect their experiences to the new knowledge (Means \& Nails, 2004).

However, lecturing method does not encourage students' initiative as it makes them passive listeners (Umar, 2016). Hence, this method has been criticised for not promoting higher order thinking skills such as conceptual understanding, independent learning and problem solving abilities (Kimmel, 
1992; Puett and Braunstein, 1991 in Saroyan and Nell, 1997). Nevertheless, on a positive note, most of the lecturers were proficient in the languages in question and displayed a strong subject content knowledge on the area of literacy and they fluently explained the literacy content in Oshikwanyama and Oshindonga.

\section{Lecture-discussion method}

By using the discussion method, lecturers started with the presentation, spoke for few minutes and then asked students to discuss key points in her/his presentation (Kaur, 2011). It was observed in some lessons that lecturers showed some characteristics of student-centered teaching. They connected their teaching to the student teachers' experiences by inviting them to get involved and sharing their cultural experiences. For example, lecturer Grace presented a listening and speaking activity to second year student teachers where she linked her presentation to student teachers' cultural experiences to extend their understanding. Her presentation focused on listening and speaking as well as the use of songs to develop listening and speaking skills. During her presentation she explained the use of play and songs with children in their classrooms and encouraged the student teachers to do this with the children.

Based on the classroom observation criteria, the classroom interaction was good because the student teachers were free and participated actively. The student teachers were given freedom to socialize and share the cultural songs with the lecturers and with others in the class. During the discussion, the lecturers offered clarifications between student comments (Kaur, 2011). Here, Grace appeared to understand that 'learning occurred as learners are actively involved in a learning process of meaning and knowledge construction' (Bhattacharjee, 2015 p.67). In conclusion, Grace was aware that literacy is acquired through social interaction and display sufficient subject knowledge through her explanation. Therefore, she located her teaching in a sociocultural perspective when she linked her lesson to the student teachers' cultural experiences.

\section{Lecture-demonstration method}

On a similar note, lecturer Marias' vast language teaching experiences made her actively teach in any phase using different teaching and learning styles. The fact that she linked her previous lesson to the one she presented that day when I observed allows student to reflect on what they leaned and logically sequence their learning. On the day of the observation, Maria asked student teachers to plan a listening 
activity using stories. It is worth mentioning that in the lesson that I observed, Maria encouraged group work and allowed verbal participation whereby student teachers were involved in more than listening. Student teachers worked in groups to plan lessons in Oshindonga; they debated on the format in their groups, learned and clarified things to others in their groups, Maria moved around the class to explain more and made sure everyone got the instructions, and guided student teachers to new discoveries.

According to Vygotsky, students perform better with teacher's guidance or working in groups than working individually (see e.g.Chatry-Komarek, 2003). There was evidence of a collaborative learning situation whereby the lecturer guided and supported student teachers while they engaged in the activity and that demonstrated some excellent teaching skills. Collaborative learning is the most effective form of learning in which learners participate actively and share their opinions without reserve (Chatry-Komarek, 2003). It is therefore worth mentioning that Maria's lesson proved an interactive one where student teachers participated freely, contributed generously, and produced lesson that showed that they were learner centred. Maria demonstrated that she was able to convey content and appeared to grasp the subject matter well. However, although Maria displayed positive features of teaching, she seems to lack knowledge and skills on the aspects of learners' prior learning: how student teachers could consider linking to learners' experience in their planning was not observed during this lesson.

\section{Lecture- modelling method}

Another powerful method used occasionally was modelling. Modelling is one of the methods that is regarded to scaffold learning because it shows rather than merely tell (Kosnik \& Beck, 2008). According to Beck, modelling is 'important for social constructivism because it is a manifestation of holism and integration: it link how we live and what we say' (2008 p.45). Lecturer Nadia used modelling method when she used resources such as big books to model good reading habits and the alphabet chart for the students to practice letter sounding.

My observation was that lecturer Nadia modelled good practices of teaching. She was observed to scaffold the student teachers' learning process. She guided the student teachers' understandings of how to use the big books to read stories to children in the classroom and at the same time modelling how she expects student teachers to show young learners how to handle the books when reading. She started the process and allowed student teachers to take over with her guidance. It is also worth mentioning that Nadia linked the book handling skills to the content of the school syllabus, which says, 
follow words from left-to-right, top-to-bottom, and page-by-page; demonstrate the proper way to handle books, e.g. hold book upright, recognise front and back cover, turn pages carefully (Namibia Ministry of Education, Arts and Culture, 2016, p. 18).

In summary, in all the lessons observed, the national language policy was supported because the mother tongue literacy content was presented in Oshindonga and Oshikwanyama. Lecturers used various teaching methods to teach mother tongue literacy in their classrooms. The methods used included the lecture/teacher talk method, lecture-discussion, and lecture-demonstration and modelled methods. Some lecturers link their teaching to student teachers' cultural experiences and, thus showed some learner-centered characteristics. However, although the lecturers demonstrated different presentation methods, when delivered the content of mother tongue literacy, their teaching methods were still dominated by lecturing.

\section{Literacy strategies and approaches}

The student teachers were exposed to different types of literacy teaching approaches. These approaches were: a) phonics: - which teaches learners the relationship between the letters of written language and individual sounds of a spoken language, b) look and say method: - which teaches learners to recognise whole words or sentences rather than individual letters, and, c) language experience approaches: - that promote reading and writing through the use of personal experiences and oral language.

It was interesting to note that although all four lecturers exposed student teachers to different types of literacy teaching strategies, they had different views about these strategies or approaches. Two lecturers strongly considered the phonics method as the best approach in approaching the teaching literacy, and this came out clearly from my interviews with them. For example, Nadia said, "For Oshiwambo that is Oshikwanyama and Oshindonga and for most Bantu languages as they say in theory, the phonic method is the best one, because actually reading strategies depend on the structure of the language" (Lecturer Nadia). Nadia continued by saying that our language if you look at the structure of Oshikwanyama or Oshindonga it is actually a bottom-up language where you start with the small chunks like the single sounds, the $a, b$, t and so on, and you put the consonants and the vowels together to make a syllable. That means that the orthography of these languages is specific to them. 
Nadia's view is in line with findings of Akyeampong et al.(2011) that suggest that in African classrooms, phonics instruction is regarded as an important strategy in teaching literacy acquisition in the early years when the regularity of phoneme-grapheme correspondence helps the reader to recognize or decode new words such as in Bantu languages (Lunganda and Kiswahili). However, linguistic scholars have questioned this assumption, noting that Bantu languages are uniquely designed with the key morpheme (unit of meaning) in the middle and affixes at the beginning and end of the word (e.g. Schroeder, 2013).

This is probably the reason why Nadia continued that "our languages are really not complex at all like English... but we just have to start with the phonics with a lot of storytelling, songs and oral " (Lecturer Nadia). Here, Nadia confirms that the teaching of phonics needs to contextualise. She brought empty containers to the class that had labels on them written in Oshindonga and Oshikwanyama (Oshikandelaoshiwambo name for sour-milk) This extended student teachers skills on how to use the context base to build on learners' prior experiences

In the same vein, Grace supports the use of phonics when she says that the "phonic method is the best one because the child would learn how to decode and give sounds to different letters, even if they or the child did not know the word before" (Lecturer Grace).

While lecturers Nadia and Grace preferred the use of the phonics method in the teaching of reading, Maria and Sara however believed that lecturers need to introduce student teachers to a variety of teaching methods in order to be able to assist all learners in their classes. To this effect, lecturer Maria postulated that "it all depend on the environment, the person, the context and on the learners who are in that class" (Lecturer Maria). She stressed that learners have different learning style, they learn differently and the community and environment learners live in are different. Therefore, lecturer Maria suggested that student teachers need to have an understanding of all the above mentioned methods and approaches in order to meet the learner's literacy learning needs. In agreement with Maria, lecturer Sara maintained,

I am personally convinced that any method could be suitable to effective teaching, not only how clever the teacher is but sometimes it depends on the environment in which those learners live, the school, and sometimes it depends on the programme the person is using (Lecturer Sara). 
However, lectures' differing views likely influenced the way they teach and may influence the teaching of the student teachers' literacy teaching in schools. As mentioned above, lecturers Nadia and Grace seem to favour the phonics method even though they introduced other reading methods to their student teachers. Lecturers Nadia and Grace views are in line with the debate in the literature, specifically as Chatry-Komarek (2003) stated, that many teachers believe that children can acquire the basic knowledge of reading by first learning the alphabet, then syllables by associating consonants and vowels, then words and sentences. This is to say, many teachers are convinced that this is the best method of starting from simple and moving to complex. Nadia and Grace's views can be located in this side of the debate, which would be in line with the cognitive perspective which believes learning how to read can happen through following a rigid order, moving from one stage to another.

Maria and Sara's views, however, are more in line with the other side of the debate whereby as stated by Snoek et al. (2011) there is no one approach that will meet the needs of all the learners. This is because children learn differently, depending on their personality, skills and experiences (ChatryKomarek, 2003). In concurrence with Chatry-Komarek, Smith (2009, p. 45) advised that it is important to remember that children are individuals and cannot be made to fit into a mould of how they supposed to act. Leaving room for teachers to choose the methods that suit their learners' needs and their environment, as decided by Maria and Sara, would offer a broader literacy learning context and more opportunities to draw on things familiar to the learners in order to make meaning of what is taught (Westbrook et al., 2013).

In general, it was evident that the lecturers regard the teaching of phonological awareness as important in learners learning literacy especially when teaching listening and speaking. Thus, the lecturers emphasised the teaching of literacy using songs, stories, rhymes, and games and they explained this during their teaching. However, in almost all the lecturers' lessons that I observed, there was no attempt made to demonstrate in detail how to teach phonological/phonemic awareness to learners, which is considered to be very important in the earliest stage in the teaching of the sound system of learning to read. As suggested in the Integrated Manual of Grades 1-3, student teachers supposed to be given the chance to practice and develop phonemic awareness first before they learn and use phonics. They should: 
1. hear rhyme and alliteration (identify sounds and words that rhyme or recognize words that start with the same sound)

2. do oddity tasks (identify the 'odd one out' in a list of rhyming words or words with the same beginning/median/ending sound)

3. orally blend words (hear separate syllables, onset/rime or letter sounds and blend then together to make a word)

4. orally segment words (orally break words into their syllables, onset/rime or letter sounds)

5. do phonemic manipulation tasks (be able to substitute and delete initial/final/vowel sounds (Ministry of Education, Arts and Culture, 2016 p.102)

The student teachers have to understand that, "Before a child learns to read print, they need to become aware of how the sounds in words work"(Armbruster, 2010). The main approach to teaching reading that I observed started with phonics. This seems to be the case with at least two lecturers, Nadia and Grace, and thus many student teachers of this study. Overall, the views given by the lecturers regarding the literacy teaching methods, especially the teaching of reading, were split. These roughly correspond to having an autonomous view of literacy, in the former case, and a sociocultural view of literacy in the latter.

The theories that offered the explanations of the teaching of phonics are exactly what is criticised by scholars such as Street (2006) and Gillon (2004). Such theories imply that literacy is an autonomous technical skill that can be acquired through following a certain order with no attention to the sociocultural context. In this case, lecturers Grace and Nadia explained that when teaching phonics, student teachers should first start with letter sounds, names, syllables, then words and sentences.

The lecturers explained that "Language Experience Approach" builds on what the learners already know and extends to new knowledge and most lecturers as well explain that student teachers should start their teaching with either a story, song or with a rhyme. However, these lecturers failed to practically demonstrate to the student teachers how they could teach using the above-mentioned methods to the learners in the class; student teachers were not given enough chances to practice the method through demonstration. Teaching using demonstration methods would contribute to student 
teachers' professional development, allowing them to not only hear and read about teaching, but also experience it (Snoek, Swennen, \& Van der Klink, 2011).

Drawn from the classroom observations, it was clear that the three of four lecturers who I observed teaching listening and speaking explained that learners need to be taught how to speak and listen in order for them to understand what was conveyed and be good listeners. These lecturers emphasised that the best way to teach literacy is to teach phonological/phonemic awareness by using stories, poems, songs, rhymes, and games in developing listening and speaking skills. However, only Grace practically linked her literacy lesson to the student teachers' cultural experiences by allowing them to discuss in their groups how traditional festivals are celebrated and which songs sung and the games played.

The training did expose the student teachers to various methods of teaching mother tongue literacy, especially in respect of reading methods such as phonics; look and say methods, whole language, and the language experience approach. However, the findings revealed that these methods were not being practically demonstrated to show how the student teachers would implement them in practices them in classrooms. With the exception of one lecturer who modelled reading using the big book, the majority of the lecturers did not present either literacy lessons or modelled lessons.

In addition, the lecturers also explained and discussed different strategies to the teaching of literacy such as modelled, shared, guided and independent reading and writing. With shared reading, Sara continued by saying that the student teachers should guide the learners to the shared reading by starting a sentence and then asking the learners to complete it. She told the students to use words from the stories to form sentences. She explained in detail the planning of guided reading or writing. She also emphasized that the planning should include differentiated activities and that the reading could either out loud or silent reading. Sara explained what independent reading is and explained to the student teachers that the learners should be asked to go to the reading corner and pick the books they want to read. It is important to encourage the learners to read the books they choose although the student teacher should always check whether these books are appropriate to the learner's age.

Although strategies such as modelled, guided, shared and independent reading and writing were comprehensively taught, the student teachers were not given an opportunity to practise and internalise these strategies during their presentation. There seems to lack pedagogical knowledge among some 
lecturers. This was confirmed by Nadia when she elaborated that: I think literacy is not easy to teach ... and I realised that this is the most difficult module for me to teach... (Nadia, a lecturer).

The data from the study revealed that some of the lecturers appear to have limited knowledge and skills in engaging all the student teachers in the lesson discussions as they clearly found it difficult to gain and hold the attention of all the student teachers.

\section{Teaching materials or resources}

While studies (Amissah 2001, UNESCO (Paris) 2000, Kosonen et al. 2006 and Benson 2004) advised that mother tongue literacy teaching would be successful if the materials in the local languages are available and used appropriately, the findings of the case study revealed that there was little or no evidence of mother tongue resources or materials to support the lecturers' teaching and student teachers learning. The study established that there is a lack of teaching and learning materials or resources that are written in Oshindonga or Oshikwanyama in the university library. Nadia, a lecturer, indicated that, although there are books such as grammar and sound system books on which they rely heavily, these represent just the bare minimum. Nadia commented as follow:

... we have grammar books which also cover the sound system - we rely on that a lot and sentence analysis, but pure academic knowledge about the Oshikwanyama and Oshindonga languages and how they are acquired, we do not have anything.

Nadia further commented regarding the content delivery when they taught purely academic knowledge and the theories and principles of literacy in mother tongue, that they did not have books in Oshindonga and/or Oshikwanyama and that this was a worrying situation. Grace explained that it became a problem when student teachers request sources and they are provided with sources that are always in English. Grace further commented:

... most of the time we have to search for information, like on the internet, and most information is in English ... when translating you came across some words that you can't find the meaning of in Oshikwanyama ... sometimes we just translate according to our own understanding and interpretations (Grace, a lecturer).

It is therefore clear that, although the ideology of the policy of mother tongue teaching is good, materials supporting the implementation of the policy are not available and that is impacting adversely 
on the proper preparation of the mother tongue literacy teachers. Thus, it hinders the proper implementation of the language policy not only for the teachers of the two identified dialects of Oshiwambo language but for the schools where they will eventually have to teach in these two dialects as well. However, despite the teaching materials or resources challenges, it was observed that the lecturers tried their best to equip their student teachers with the knowledge on how to develop teaching and learning materials in Oshindonga and Oshikwanyama to help them teach literacy in schools. For example, Nadia together with the students created big books, which she used when she was modelling good reading habit to students. This practice is supported by the available literature; it is suggested that trainers should encourage their student teachers to learn how to use graded materials effectively and to create their own instructional materials (Dennis \& Malone, 2011).

\section{Practical activities and microteaching}

According to the UNAM Prospectus for 2016, the practical course "aims to provide student teachers with skills to compile and present various school subjects plan and develop instructional materials that support learner's engagement" ( $p$ 34). The programme requires student teachers to carry out practical activities through class presentations and microteaching. Hence, during the practical lessons, some groups just explained the steps one has to follow when teaching a particular topic or concept, while some groups did microteaching having been given the opportunity to plan and present activities and demonstrate how to teach specific mother tongue literacy content as if they were with learners in a real class.

The lecturers assessed the knowledge and skills portrayed and sometimes assessed with the specific intention to give marks or assess the student teachers' knowledge and skills. They recorded what needed to be corrected and after the presentation made the corrections. For example, lecturer Saara attested that

we have allocated time for practical, every second week we have two hours for practical. For example, if we have covered how shared reading is taught, that is the theory; we give tasks to students to practice what they learned during the theory time. The students are place in the slots who to be evaluated". 
My findings also show that because the literacy content was often presented without proper demonstrations in most cases of how it could be practically applied, some student teachers struggled to practice their assigned tasks. It was observed that some student teachers did not rehearse before making their presentations, which if they did might have helped them to convey correct information and have eye contact with the imaginary learners.

During the practical lessons, the lecturers also gave a chance to student teachers to present and practice all the Environmental Studies and Mathematics contents that they learned in English. Nadia pointed out that they were to articulate mathematical concepts in Oshindonga and Oshikwanyama. Unfortunately, they ran out of time during the practical lesson.

\section{Conclusions}

This study examined how student teachers are prepared to teach literacy in Oshindonga and Oshikwanyama languages looking at the content taught and the methods and strategies used. Classroom observations revealed that lecturers were proficient in the language in questions and they explained the literacy content in Oshindonga and Oshikwanyama. The main teaching method used was the teachertalk teaching method, which was dominated by the teacher just presenting the content using the power point, thus limiting the student teachers' in-depth understanding of the subject content. Although some of the lessons observed did provide evidence of good literacy practices with the lecturers presenting and discussing with the student teachers and also demonstrating and modelling to the student teachers how things should be done, it was observed that in the four lecturers' lessons, teacher-talk methods dominated the mother tongue literacy content delivery. It was also noted that all the lecturers emphasised the importance and value of stories, songs, rhymes, and games in the teaching of literacy skills to young learners. It was also evident that the lecturers tried to expose the student teachers to the different methods and approaches in respect of mother tongue literacy teaching and, especially, reading methods such as phonics, look and say methods, whole word study, and the language experience approach. It was also observed that literacy teaching strategies such as modelled, guided, shared and independent reading and writing were comprehensively explained. However, the student teachers were not given an opportunity to practise and internalise these strategies that they learned during the lesson. Despite the fact that the student teachers' cultural experiences were utilised in some lessons, it is worth mentioning that in the majority of the lessons observed, the student teachers' cultural experiences were 
not used to teach literacy. The study established that there is a lack of teaching and learning materials/resources that are written in Oshindonga or Oshikwanyama in the university library.

\section{References}

Akyeampong, K., Pryor, J., Westbrook, J., \& Lussier, K. (2011). Teacher preparation and continuing professional development in Africa: Learning to teach early reading and mathematics.Online]Www.Sussex.Ac.uk/cie/documents/tpa-Synthesis-Report-july2011.Pdf,

Amineh, R., \& Asl, H. (2015). Review of constructivism and social constructivism. Journal of Social Sciences, Literature and Languages, 1(1), 9-16.

Amissah, P. (2001). Transformation of bilingual teacher training: Learning how to teach in the first language. Improving Educational Quality (IEQ): The University of Pittsburgh. American Institutes for Research

Armbruster, B. B. (2010). Put reading first: The research building blocks for teaching children to read: Kindergarten through grade 3 Diane Publishing.

Angula, N. (1993). Towards education for all: A development brief for education, culture, and training. Windhoek: Gamsberg Macmillan.

Bausch, L. S., \& Voorhees, S. C. (2008). Retrospective discourse discussions: How teacher talk enables one novice literacy teacher to make sense of complex teaching problems. The Teacher Educator, 43(2), 109-133.

Bell, J. (2005). Doing your research project:A guide for first-time researchers in education. Health and Social Science-4/E. Open University Press. McGraw-Hill

Benson, C., \& Plüddemann, P. (2010). Empowerment of bilingual education professionals: The training of trainers programme for educators in multilingual settings in southern africa (TOTSA) 2002-2005. International Journal of Bilingual Education and Bilingualism, 13(3), 371-394.

Bhattacharjee, J. (2015). Constructivist approach to Learning-An effective approach of teaching learning. International Research Journal of Interdisciplinary \& Multidisciplinary Studies, 1(4) 
Bloch, C. (2005). Enabling effective literacy learning in multilingual south African early childhood classrooms PRAESA.

Chall, J. S. (1983). Stages of reading development. New York, NY: McGraw-Hill.

Chatry-Komarek, M. (2003). Literacy at stake: Teaching reading and writing in african achoola. Namibia: Gamsberg Macmillan Publishers.

Cresswell, J. W. (2013). Qualitative inquiry and research design: Choosing among five approaches (3rd ed.). Lincoln. Sage.

Cummins, J. (2001). Bilingual children's mother tongue: Why is it important for education? Sprogforum, 19, 15-20.

Darling-Hammond, L., \& Bransford, J. (2007a). Preparing teachers for a changing world: What teachers should learn and be able to do John Wiley \& Sons.

Davidson, K. (2010). The integration of cognitive and sociocultural theories of literacy development: Why? how? Alberta Journal of Educational Research, 56(3)

Dutcher, N. (2003). Promise and perils of mother tongue education. Retrieved November, 28, 2009.

Gacheche, K. (2010). Challenges in implementing a mother tongue-based language-in-education policy: Policy and practice in kenya. POLIS Journal, 4, 1-45.

Gain, P. (2004). Learning about literacy: Teachers' conceptualisation and enactments of early pedagogies in South African grade one classroom. A thesis submitted to the faculty of humanities, University of the Witwatersrand. Johannesburg

Gillon, G. T. (2004). Phonological awareness: From research to practice Guilford Press.

Hammond, L. D., \& Bransford, J. D. (2005). Preparing teachers for a changing world: What teachers should learn and be able to do Jossey-Bass.

Heredia, B. A. (2011). Preparing Teachers for Effective Literacy Instruction in the Elementary Grades: Two-Year Teacher Preparation Programs in Ontario,

Honan, E., Exley, B., Kervin, L., Simpson, A., \& Wells, M. (2013). Rethinking the literacy capabilities of pre-service primary teachers in testing times. Australian Journal of Teacher Education, $38(10), 48-63$. 
Hossain, T. (2o13). Literacy as social practice. Educational Studies. International Christian University, 51, 125-132.

Hudson, S., Dossel, K., \& Hudson, P. (2009). Reading squadron: Crossing borders in literacy experiences for preservice teachers. Brisbane. Queensland University

Karan, E., \& Morren, D. (2013). Teacher education curriculum supplement for pre-service teacher candidates expecting to work in mother tongue-based multilingual education (MTB-MLE) programs, SIL international.

Kaur, G. (2011). Study and analysis of lecture model of teaching. Int J Educational Planning Admin, 1(1), 9-13.

Kosnik, C., \& Beck, C. (2008). We taught them about literacy but what did they learn? The impact of a pre-service teacher education program on the practices of beginning teachers. Studying Teacher Education, 4(2), 115-128.

Lewin, K. M. (2004). The pre-service training of teachers-does it meet its objectives and how can it be improved. Global Monitoring Report Or to UNESCO. "Paper Commissioned for the EFA Global Monitoring Report.the Quality Imperative”Retrieved from Efareport@Unesco.Org,

Matthew B.. Miles, Huberman, A. M., \& Saldaña, J. (2014). Qualitative data analysis: A methods sourcebook Sage.

Mosley, M. (2010). Becoming a literacy teacher: Approximations in critical literacy teaching. Teaching Education, 21(4), 403-426.

Mulkeen, A. (2010). Teachers in anglophone africa issues in teacher supply. Training and Management, Washington, World Bank,

Mulkeen, A., \& Crowe-Taft, N. (2010). Teacher attrition in Sub-Saharan Africa: The neglected dimension of the teacher supply challenge. A Review of Literature,

Namibia Ministry of Education, Arts and Culture (MEAC). (2016). The national curriculum for basic education. NIED. Unpublished manuscript.

Ng, P. F., \& Yeo, K. J. (2013). Emergent literacy in a printrich multilingual home environment. Internal Journal of Humanities and Social Science, 3(13), 146-155. 
Nomlomo, V., \& Desai, Z. (2014). Reflections on the development of a pre-service language curriculum for the BEd (foundation phase). South African Journal of Childhood Education, 4(3), 87-102.

Pang, E. S., Muaka, A., Bernhardt, E. B., \& Kamil, M. L. (2003). Teaching reading International Academy of Education Brussels, Belgium.

Papatheodorou, T. (2007). Supporting the mother tongue: Pedagogical approaches. Early Child Development and Care, 177(6-7), 751-765.

Patton, M. Q. (2005). Qualitative research Wiley Online Library.

Purcell-Gates, V. (2004). Family literacy as the site for emerging knowledge of written language. Handbook of Family Literacy, , 101-116.

Purcell-Gates, V., Degener, S., Jacobson, E., \& Soler, M. (2001). Taking literacy skills home. Focus on Basics, 4, 1-7.

Rai, V., Rai, M., Phyak, P., \& Rai, N. (2011). Multilingual education in Nepal: Hearsay and reality. A report. UNESCO, Nepal

Smith, K. (2009). Transnational teaching experiences: An under-explored territory for transformative professional development. International Journal for Academic Development, 14(2), 111-122.

Snoek, M., Swennen, A., \& Van der Klink, M. (2011). The quality of teacher educators in the European policy debate: Actions and measures to improve the professionalism of teacher educators. Professional Development in Education, 37(5), 651-664.

Stone, R. P. (2012). A Professional Development Program for the Mother Tongue-Based Teacher: Addressing Teacher Knowledge and Attitudes about MTBMLE,

Street, B. (2003). What's "new" in new literacy studies? critical approaches to literacy in theory and practice. Current Issues in Comparative Education, 5(2), 77-91.

Street, B. V. (2006). Autonomous and ideological models of literacy: Approaches from new literacy studies. Media Anthropology Network, 17

Swennen, A., \& Van der Klink, M. (2009). Epilogue: Enhancing the profession of teacher educators. Becoming a Teacher Educator.Theory and Practice for Teacher Educators, , 219-227. 
Vygotsky, L. S. (1989). Concrete human psychology. Soviet Psychology, 27(2), 53-77.

Westbrook, J., Durrani, N., Brown, R., Orr, D., Pryor, J., Boddy, J., et al. (2013). Pedagogy, curriculum, teaching practices and teacher education in developing countries. Fnal Report. Education rigorous literature review. Department for International Development. University of Sussex

\section{Appendix A: Interview Schedule for Lecturers}

The purpose of this guide is to elicit teacher educators' views of their experiences of teaching students how to teach their mother tongue.

Name:

Language:

Professional qualification:

UNAM campus:

Date:

1. How long have you been a Junior Primary lecturer?

2. What have been your most memorable experiences of being a Junior Primary lecturer?

3. What are your understandings of the language policy for schools? Please explain.

4. How is language policy integrated into the curriculum? Please explain.

5. What language do you use when teaching student teachers? Why?

6. What are your views on mother tongue teaching?

7. What are the advantages and disadvantages of mother tongue teaching?

8. Have you been trained to teach in the mother tongue? How? Was the training effective?

9. What literacy skills do you teach? 
10. What strategies do you use to teach literacy skills (listening, speaking, reading and writing) in the mother tongue?

10.1How do you teach listening skills?

10.2How do you teach speaking skills?

10.3How do you teach reading skills?

10.4 How do you teach writing skills?

11. What do you think are the best strategies for teaching literacy skills?

12. What challenges have you experienced when teaching literacy (listening, speaking, reading and writing) in the mother tongue?

13. Why do you consider these to have been the challenges?

14. How do you overcome these challenges?

15. Why do you think it is important to teach in the mother tongue in the Junior Primary Phase (Pre-primary to Grade 3)?

16. Do you have a specific programme that you follow when teaching mother tongue literacy? Please explain.

17. Are there materials available in the language that is used as the medium of instruction?

18. Are they adequate? If not, how could they be improved?

19. Do you have any other concluding comments? 


\section{Appendix E: Classroom Observation Guide for Teacher Educators}

The purpose of this guide is to obtain first-hand data on what lecturers practise in the classroom when preparing future teachers to teach mother tongue literacy.

UNAM campus:

Lecturer:

Language:

Date of visit:

Topic:

No. of students:

Date:

1. How does the lecturer interact with the student teachers by way of a social practice?

2. How does the lecturer assist student teachers to translate the mother tongue policy into practice?

3. What are the literacy skills that are being taught?

4. What teaching strategies does the lecturer use to enhance mother tongue literacy?

5. What strategies and materials does the lecturer use to support the student teachers' understanding of the content of literacy skills (listening, speaking, reading and writing) in the mother tongue?

6. How does the lecturer assist the student teachers to connect what they already know with the new information they receive?

7. What teaching materials and resources does the lecturer use to support literacy learning in the mother tongue?

8. How does the lecturer assess the student teachers' literacy learning?

9. Is the lecturer proficient in the language used as the medium of instruction?

10. Anything striking about the lesson?

11. Strengths and/or weaknesses of the lesson 